\title{
Antimalarial Effects of Peptide Inhibitors of a Plasmodium falciparum Cysteine Proteinase
}

\author{
Philip J. Rosenthal, Wendy S. Wollish, James T. Palmer, * and David Rasnick* \\ Department of Medicine, San Francisco General Hospital and University of California, San Francisco, California 94143; \\ and ${ }^{*}$ Prototek, Inc., Dublin, California 94568
}

\begin{abstract}
We previously identified a Plasmodium falciparum trophozoite cysteine proteinase (TCP) and hypothesized that it is required for the degradation of host hemoglobin by intraerythrocytic malaria parasites. To test this hypothesis and to evaluate TCP as a chemotherapeutic target, we examined the antimalarial effects of a panel of peptide fluoromethyl ketone proteinase inhibitors. For each inhibitor, effectiveness at inhibiting the activity of TCP correlated with effectiveness at both blocking hemoglobin degradation and killing cultured parasites. Benzyloxycarbonyl ( $\mathrm{Z}$ )-Phe-Arg- $\mathrm{CH}_{2} \mathrm{~F}$, the most potent inhibitor, inhibited TCP at picomolar concentrations and blocked hemoglobin degradation and killed parasites at nanomolar concentrations. Micromolar concentrations of the inhibitor were nontoxic to cultured mammalian cells. These results support the hypothesis that TCP is a necessary hemoglobinase and suggest that it is a promising chemotherapeutic target. (J. Clin. Invest. 1991. 88:1467-1472.) Key words: chemotherapy • hemoglobin • malaria $\bullet$ protease $\bullet$ proteinase inhibitor
\end{abstract}

\section{Introduction}

Infection with Plasmodium falciparum, the most virulent human malaria pathogen, is estimated to be responsible for over one million deaths per year $(1,2)$. Recent efforts at the control of falciparum malaria have generally been unsuccessful, in large part due to the increasing resistance of populations of $P$. falciparum to available antimalarial drugs $(3,4)$. Thus, there is a great need for the identification of novel chemotherapeutic targets and the evaluation of potential new antimalarial compounds that act on these targets.

Erythrocytic malaria parasites degrade host erythrocyte hemoglobin as a principal source of free amino acids for parasite protein synthesis (5). Hemoglobin degradation takes place in the malarial food vacuole, an acidic organelle that appears to be analogous to mammalian lysosomes (6). We previously showed that cysteine proteinase activity is required for hemoglobin degradation by $P$. falciparum (7), and we identified a $P$. falciparum trophozoite cysteine proteinase $(\mathrm{TCP})^{1}$ that had

Address reprint requests to Dr. Rosenthal, Box 0811, University of California, San Francisco, CA 94143.

Received for publication 20 February 1991 and in revised form 27 June 1991.

1. Abbreviations used in this paper: AMC, amino-4-methyl-coumarin; TCP, trophozoite cysteine proteinase.

J. Clin. Invest.

(c) The American Society for Clinical Investigation, Inc. $0021-9738 / 91 / 11 / 1467 / 06 \$ 2.00$

Volume 88, November 1991, 1467-1472 similar biochemical properties to the lysosomal cysteine proteinase cathepsin L (7-9). We hypothesized that TCP is a hemoglobinase that is required for the hydrolysis of globin in the malarial food vacuole.

There is increasing evidence that proteinases can be important pharmacological targets. Inhibitors of a host proteinase, angiotensin-converting enzyme, are used widely to treat cardiovascular disease $(10,11)$. Peptide inhibitors of a viral proteinase, the aspartic proteinase of HIV-1, specifically inhibit the HIV-1 proteinase and block the proteolytic processing of HIV1 at micromolar concentrations (12-14). In this report we describe the effects of fluoromethyl ketone peptide proteinase inhibitors on the enzymatic activity of TCP and on the development and viability of cultured malaria parasites. Our results support the hypothesis that TCP is a necessary hemoglobinase and a promising target for chemotherapy. Furthermore, we identified a compound that was highly active against TCP and cultured parasites at concentrations far below those shown to be nontoxic to mammalian cells.

\section{Methods}

Parasite culture and preparation of trophozoite extracts. Malaria parasites were cultured in human erythrocytes (purified of leukocytes and platelets) as previously described (8). All experiments were with the Itg2 strain of $P$. falciparum except when noted. To prepare trophozoite extracts, trophozoite-infected erythrocytes $\left(10^{9}\right.$ to $10^{10}$ parasites per preparation) were incubated with $0.1 \%$ (wt/vol) saponin in PBS to lyse erythrocyte membranes and washed three times with ice-cold PBS. Parasite proteins were then solubilized in water and subjected to two freeze-thaw cycles; the supernatant after centrifugation $(13,000 \mathrm{~g}, 10$ $\min , 4^{\circ} \mathrm{C}$ ) was collected and is referred to as trophozoite extract.

Proteolytic activity assays. The activity of TCP in trophozoite extracts was assayed spectrofluorometrically with the peptide substrate benzyloxycarbonyl (Z)-Phe-Arg-amino-4-methyl-coumarin (AMC), a specific substrate for $\operatorname{TCP}(7,9)$, the only cysteine proteinase identified in trophozoite extracts (8). A panel of fluoromethyl ketone inhibitors known to have had a wide range of effectiveness in the inhibition of other cysteine proteinases was provided by Prototek, Inc., Dublin, CA (U. S. patent no. 4,518,528, issued May 21, 1985). Trophozoite extracts were incubated (in $0.1 \mathrm{M}$ sodium acetate, $10 \mathrm{mM}$ dithiothreitol, $\mathrm{pH}$ 5.5) with the appropriate concentration of inhibitor for $30 \mathrm{~min}$ at room temperature, and then $50 \mu \mathrm{M}$ Z-Phe-Arg-AMC was added, fluorescence ( $380 \mathrm{~nm}$ excitation, $460 \mathrm{~nm}$ absorbance) was measured continuously over $30 \mathrm{~s}$, and the slope of fluorescence over time (representing TCP activity) was determined. Correlation coefficients for the slopes were generally $>0.99$, except when activity was very low. Plots of percent control activity against concentration inhibitor (two to six assays per inhibitor concentration) were used to determine the concentrations that inhibited $50 \%$ activity. The effects of Z-Phe-Arg- $\mathrm{CH}_{2} \mathrm{~F}$ on human cathepsin B and human cathepsin L (Enzyme Systems Products, Dublin, CA) were determined with the same fluorescent assay and the same substrate (Z-Phe-Arg-AMC) as used for assays of TCP.

Hemoglobin degradation assays. Ring-stage parasites grown in $0.25-\mathrm{ml}$ cultures were incubated with inhibitors (solubilized in DMSO; final concentration DMSO $=1 \%$ by volume, a concentration that had 
no observable effect on controls) in RPMI culture media. Aliquots were removed, smeared, and stained with Giemsa at various time points. After $24 \mathrm{~h}$ of culture, when the parasites were at the trophozoite stage, a block in hemoglobin degradation was identified by the appearance of an abnormal, dark-staining food vacuole (see Fig. 2). This appearance was previously correlated with a block in the hydrolysis of globin (5), and this correlation has been confirmed in these studies for Z-Phe-Arg- $\mathrm{CH}_{2} \mathrm{~F}$ (see Fig. 3). The lowest concentration at which $>50 \%$ of parasites had an obvious food vacuole abnormality is reported in Table I. For all inhibitors, the next higher concentration assayed ( $3.3 \times$ the reported concentration) caused $>95 \%$ of parasites to have the food vacuole abnormality. To determine the length of incubation with an inhibitor required for an inhibitory effect, ring-stage parasites were incubated with the inhibitor for 2,4, or $6 \mathrm{~h}$, the inhibitor was removed by multiple washes, and cultures were assayed after $24 \mathrm{~h}$ for the presence of abnormal food vacuoles.

Parasite viability assays. Aliquots from cultures grown with inhibitors as described above were also smeared and stained with Giemsa after $48 \mathrm{~h}$, when control cultures contained nearly all new ring-stage parasites. Parasitemias for each culture were determined by counts of 500 erythrocytes each by two individuals. Plots of percent control parasitemia against concentration (3-12 assays per inhibitor concentration) were used to determine the concentration at which each inhibitor inhibited $50 \%$ new ring formation $\left(\mathrm{LD}_{\mathrm{s}_{0}}\right)$. To determine the length of incubation with an inhibitor required for an inhibitory effect, ring-stage parasites were incubated with the inhibitor for 2,4, or $6 \mathrm{~h}$, the inhibitor was removed by multiple washes, and cultures were analyzed after $48 \mathrm{~h}$ by comparing the ring parasitemia with that of untreated controls.

Enzyme kinetics. Since the most effective fluoromethyl ketone inhibitors were rapidly active at low concentrations, calculations for these irreversible inhibitors were based on second order conditions (15). The concentration of TCP in trophozoite extracts was titrated with the inhibitor L-transepoxy-succinyl-leucylamido-(4-guanidino)butane (E-64) and the substrate Z-Phe-Arg-AMC (16). For kinetic assays, inhibitors were incubated with trophozoite extracts at equimolar concentrations (both $17 \mathrm{nM}$ ), and TCP activity was assayed after various periods of incubation by adding Z-Phe-Arg-AMC and following the increase in fluorescence over $30 \mathrm{~s}$ as described above. Half-lives

Table I. Effects of Fluoromethyl Ketones on TCP and on Cultured Malaria Parasites

\begin{tabular}{|c|c|c|c|}
\hline \multirow[b]{2}{*}{ Inhibitor } & \multicolumn{3}{|c|}{ Inhibitor concentration yielding } \\
\hline & $\begin{array}{l}50 \% \text { inhibition } \\
\text { of TCP } \\
\text { activity }\end{array}$ & $\begin{array}{l}>50 \% \text { block in } \\
\text { hemoglobin } \\
\text { degradation }\end{array}$ & $\begin{array}{c}\mathbf{L D}_{\text {s0 }} \text { cultured } \\
\text { parasites }\end{array}$ \\
\hline & $n M$ & $\mu M$ & $\mu M$ \\
\hline Z-Phe-Arg- $\mathrm{CH}_{2} \mathrm{~F}$ & 0.36 & 0.10 & 0.064 \\
\hline Z-DPhe-Arg- $\mathrm{CH}_{2} \mathrm{~F}$ & 14 & 1.0 & 0.65 \\
\hline Z-Phe-Ala- $\mathrm{CH}_{2} \mathrm{~F}$ & 28 & 3.3 & 1.80 \\
\hline Z-Phe-Phe- $\mathrm{CH}_{2} \mathrm{~F}$ & 50 & $\mathrm{ND}^{*}$ & ND \\
\hline Z-DTyr-Ala- $\mathrm{CH}_{2} \mathrm{~F}$ & 600 & 33 & 22 \\
\hline Z-DPhe-Ala- $\mathrm{CH}_{2} \mathrm{~F}$ & 1,300 & 100 & 58 \\
\hline Boc-Asp- $\mathrm{CH}_{2} \mathrm{~F}$ & $>100,000$ & $>100$ & $>100$ \\
\hline
\end{tabular}

A fluorescent assay of TCP activity and microscopic assays of parasite development and multiplication were performed with controls and multiple concentrations of each inhibitor. The concentrations yielding 50\% inhibition of TCP activity, > 50\% of parasites with a block in hemoglobin degradation, and a $50 \%$ reduction in parasite multiplication are noted. D represents the D-stereoisomer of the amino acid after this symbol.

* ND, not done due to limitations of RPMI solubility of Z-Phe-Phe$\mathrm{CH}_{2} \mathrm{~F}$. of inhibition were calculated from plots of percent control activity against time. The apparent second order rate constants of inhibition were calculated based on the equation: $1 /[E]=1 /[E]_{0}+k_{\text {inhib }}(t)$, where $[E]_{0}$ is the starting enzyme concentration, $[E]$ is the residual enzyme concentration, $k_{\text {inhib }}$ (also referred to as $k_{\text {ass }}$ ) is the rate constant of inhibition, and $t$ is time (15). Plots of $1 /[E]$ against $t$ were drawn, and slopes, representing $k_{\text {inhib }}$, were calculated.

$S D S-P A G E$. For the evaluation of the hydrolysis of globin, synchronized ring-stage parasites were cultured with and without $100 \mathrm{nM} \mathrm{Z-}$ Phe-Arg- $\mathrm{CH}_{2} \mathrm{~F}$. After $24 \mathrm{~h}$ of culture, when the parasites were at the trophozoite stage, erythrocyte membranes were lysed with $0.1 \%$ (wt/ vol) saponin, the parasites were washed three times with PBS to remove erythrocyte cytoplasmic proteins, and parasite proteins were solubilized in SDS sample buffer and separated by SDS-PAGE under reducing conditions. For the evaluation of the specific inhibition of TCP, gelatin substrate SDS-PAGE of soluble trophozoite proteins was performed as previously described (8). Z-Phe-Arg- $\mathrm{CH}_{2} \mathrm{~F}(100 \mathrm{nM})$ or control (water) was incubated with the trophozoite extract ( $1 \mathrm{~h}$ on ice) before the addition of nonreducing SDS sample buffer and was also added to the buffer $(0.1 \mathrm{M}$ sodium acetate, $\mathrm{pH} 6.0,10 \mathrm{mM}$ dithiothreitol) in which the gel lane incubated (overnight at $37^{\circ}$ ) before it was stained with Coomassie Blue. For the evaluation of the effects of Z-PheArg- $\mathrm{CH}_{2} \mathrm{~F}$ on TCP in intact parasites, early trophozoites were cultured in various concentrations (33-1,000 nM) of Z-Phe-Arg- $\mathrm{CH}_{2} \mathrm{~F}$ for $6 \mathrm{~h}$, erythrocyte membranes were lysed with $0.1 \%$ saponin, the parasites were washed three times with PBS, and parasite proteins were solubilized in nonreducing SDS sample buffer and analyzed by gelatin substrate SDS-PAGE.

Evaluation of the toxicity of peptide fluoromethyl ketones in mammalian cell lines. The cell lines assayed were human foreskin fibroblasts, MRC-5 (human fetal lung), Int 407 (human embryonic intestine), and Flow 2000 (human fetal lung). Cultures of actively growing cells were set up in duplicate on microwell plates and incubated with 1 , 10 , or $100 \mu \mathrm{M} \mathrm{Z}$-Phe-Arg- $\mathrm{CH}_{2} \mathrm{~F}$ or, for controls, with equal concentrations of DMSO (up to $1 \%$ by volume), in RPMI culture media. Cycloheximide $(1 \mathrm{mg} / \mathrm{ml}, 10 \mathrm{mg} / \mathrm{ml})$ was used as a control for toxicity. The cultures were maintained for $4 \mathrm{~d}$, and each day aliquots were removed and assayed for toxicity by the following assays. (a) Microscopic inspection and counting: the viability of a culture was assessed based on the appearance of the cells (toxicity was evidenced by rounded, nonconfluent cells) and cell counts (assessed with a hemocytometer after aliquots were removed and treated with $0.05 \%$ trypsin [wt/vol]). (b) Trypan blue: cells were stained with $0.04 \%$ trypan blue (wt/vol) and treated with trypsin as above, and blue colored cells, indicating toxicity, were counted. (c) 3-(4,5-dimethylthiazol-2yl)-2,5-diphenyl tetrazolium bromide reduction. The assay, performed according to Denizot and Lang (17), relies on the cleavage in only viable cells of the tetrazolium salt 3-(4,5-dimethylthiazol-2-yl)-2,5-diphenyl tetrazolium bromide by the mitochondrial enzyme succinate dehydrogenase.

\section{Results}

Inhibition of TCP activity and parasite development by fluoromethyl ketone proteinase inhibitors. In order to clarify the biological role of TCP, we studied the effects of a panel of peptide fluoromethyl ketone proteinase inhibitors $(18,19)$ on the activity of TCP, on the degradation of hemoglobin by cultured malaria parasites, and on the viability of cultured parasites (Table I). For each inhibitor, effectiveness at inhibiting the activity of TCP correlated with effectiveness at both blocking hemoglobin degradation and killing cultured parasites. The effects of the inhibitors varied over a wide range of concentrations, but in each case the concentration of inhibitor required to block hemoglobin degradation and kill parasites was approximately two orders of magnitude greater than that required to inhibit isolated TCP. The fact that increased concentrations of inhibi- 

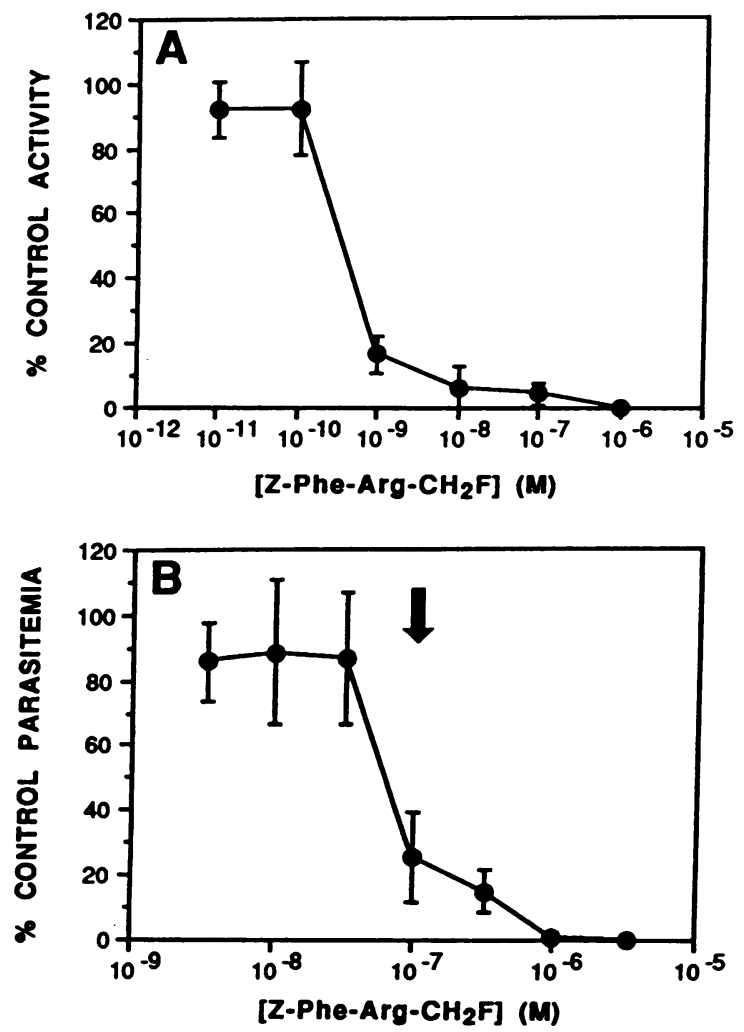

Figure 1. Effects of Z-Phe-Arg- $\mathrm{CH}_{2} \mathrm{~F}$ on TCP and on cultured malaria parasites. Data is presented to demonstrate the inhibitory effects of a range of concentrations of Z-Phe-Arg- $\mathrm{CH}_{2} \mathrm{~F}$ on $(A)$ the activity of TCP and $(B)$ the viability of cultured parasites. Error bars represent standard deviations of results (2-6 assays per concentration for activity, 3-12 assays per concentration for parasite viability). In $B$ the arrow represents the lowest concentration $(100 \mathrm{nM})$ at which $>50 \%$ of parasites had an abnormal food vacuole demonstrative of a block in globin hydrolysis (see Fig. 3).

tors were required to demonstrate biological effects can probably be explained by limitations in the transport of the inhibitors to the malarial food vacuole.

The most potent inhibitor in each assay was Z-Phe-Arg$\mathrm{CH}_{2} \mathrm{~F}$, an effective inhibitor of cathepsin $\mathrm{L}$ and other cysteine proteinases (20). Z-Phe-Arg- $\mathrm{CH}_{2} \mathrm{~F}$ blocked the activity of TCP at picomolar concentrations (Fig. $1 \mathrm{~A}$ ) and its rate constant of inhibition was approximately equal to those of the most potent inhibitors of other cysteine proteinases (Table II; [21]). Z-PheArg- $\mathrm{CH}_{2} \mathrm{~F}$ blocked hemoglobin degradation and killed cultured parasites at nanomolar concentrations (Fig. $1 B$ ). Quantitatively similar results were recently obtained with two related peptide fluoromethyl ketones in assays only of parasite killing (22). Within $4 \mathrm{~h}$ after incubation with $100 \mathrm{nM} \mathrm{Z-Phe-Arg-}$ $\mathrm{CH}_{2} \mathrm{~F}$, the food vacuoles of parasites incubated with Z-PheArg- $\mathrm{CH}_{2} \mathrm{~F}$ were abnormally dark-staining, presumably due to a block in globin hydrolysis, and with longer incubation the parasites did not develop beyond the trophozoite stage (Fig. 2). Under the same conditions used to study the inhibition of TCP, the concentration of Z-Phe-Arg- $\mathrm{CH}_{2} \mathrm{~F}$ required for $50 \%$ inhibition of cathepsin $\mathrm{L}$ was $400 \mathrm{pM}$ and that for $50 \%$ inhibition of cathepsin B was $2 \mathrm{nM}$.

Z-Phe-Arg- $\mathrm{CH}_{2} \mathrm{~F}$ blocked hemoglobin degradation rapidly and irreversibly. When the inhibitor (100 $\mathrm{nM})$ was added to trophozoites for 2,4 , or $6 \mathrm{~h}$ and then removed by multiple washes, hemoglobin degradation and parasite multiplication were irreversibly blocked. After $24 \mathrm{~h}$, when control cultures contained new ring stage parasites, the cultures that had been briefly incubated with Z-Phe-Arg- $\mathrm{CH}_{2} \mathrm{~F}$ contained no new ring forms and the parasites contained abnormal food vacuoles demonstrative of a block in hemoglobin degradation. In contrast, when hemoglobin degradation was blocked by the reversible cysteine proteinase inhibitor leupeptin, this effect was reversed by washing (7).

The effects of Z-Phe-Arg- $\mathrm{CH}_{2} \mathrm{~F}$ on four different strains of $P$. falciparum (Itg2, a Brazilian chloroquine-resistant strain, FCR3, a West African chloroquine-resistant strain, W-2, a Southeast Asian chloroquine-resistant strain, and D6, a West African chloroquine-sensitive strain) were essentially identical. For all four strains, the concentrations of Z-Phe-Arg- $\mathrm{CH}_{2} \mathrm{~F}$ required to block hemoglobin degradation and to kill parasites were approximately those listed in Table I for strain Itg2.

$\mathrm{Z}$-Phe-Arg- $\mathrm{CH}_{2} \mathrm{~F}$ caused the accumulation of undegraded globin. The morphological changes in the malarial food vacuole induced by the fluoromethyl ketones (Fig. 2) were accompanied by the accumulation of undegraded globin. Parasites were isolated from erythrocytes and their proteins separated by SDSPAGE. Globin was undetectable in control parasites, as it was presumably rapidly hydrolized after transport to the food vacuole. In contrast, globin monomers were the most abundant SDS-soluble proteins in parasites that had been incubated with Z-Phe-Arg- $\mathrm{CH}_{2} \mathrm{~F}$ (Fig. 3). These results suggest that Z-Phe-Arg$\mathrm{CH}_{2} \mathrm{~F}$ killed parasites through a specific block in globin hydrolysis.

Z-Phe-Arg- $\mathrm{CH}_{2} \mathrm{~F}$ specifically inhibited TCP. The effects of the fluoromethyl ketone inhibitors on cultured parasites appeared to be due to the specific inhibition of TCP. TCP represented the only cysteine proteinase activity identified on gelatin substrate polyacrylamide gels of trophozoite extracts (8) and this activity was completely ablated by Z-Phe-Arg- $\mathrm{CH}_{2} \mathrm{~F}$ (Fig. 4). A 6-h incubation of cultured parasites with $100 \mathrm{nM}$ Z-Phe-Arg- $\mathrm{CH}_{2} \mathrm{~F}$, the lowest concentration tested that caused a food vacuole abnormality in the majority of parasites (Table I), completely inhibited TCP, and incubation with $33 \mathrm{nM}$ Z-PheArg- $\mathrm{CH}_{2} \mathrm{~F}$, which caused an abnormality in $<10 \%$ of parasites, partially inhibited TCP when the activity of whole parasites was assayed with gelatin substrate SDS-PAGE (not shown). These results suggest that the block in the hydrolysis of globin

Table II. Kinetics of Inhibition of TCP by Fluoromethyl Ketones

\begin{tabular}{|c|c|c|}
\hline Inhibitor & $t_{1 / 2}$ & $k_{\text {inhib }}$ \\
\hline & $\min$ & $M^{-1} s^{-1}$ \\
\hline Z-Phe-Arg- $\mathrm{CH}_{2} \mathrm{~F}$ & 5.0 & $4.3 \times 10^{5}$ \\
\hline Z-DPhe-Arg- $\mathrm{CH}_{2} \mathrm{~F}$ & 27 & $4.4 \times 10^{4}$ \\
\hline Z-Phe-Ala- $\mathrm{CH}_{2} \mathrm{~F}$ & 36 & $5.4 \times 10^{4}$ \\
\hline Z-Phe-Phe- $\mathrm{CH}_{2} \mathrm{~F}$ & 26 & $4.8 \times 10^{4}$ \\
\hline
\end{tabular}

The inhibitors were incubated with trophozoite extracts under second-order conditions ([enzyme] $=[$ inhibitor $]=17 \mathrm{nM}$ ) and enzyme activity was determined at various time points with the Z-Phe-ArgAMC fluorogenic substrate. Half-lives of inhibition $\left(t_{1 / 2}\right)$ and apparent second-order rate constants of inhibition $\left(k_{\text {inhib }}\right)$ were calculated as described in Methods. 



Figure 2. Effects of Z-Phe-Arg- $\mathrm{CH}_{2} \mathrm{~F}$ on parasite development. Trophozoite-stage parasites were incubated with $(A)$ no inhibitor or $(B) 100 \mathrm{nM}$ Z-Phe-Arg- $\mathrm{CH}_{2} \mathrm{~F}$ and aliquots were smeared and stained with Giemsa at $0,4,8$, and $24 \mathrm{~h}$ after the inhibitor was added. After $4 \mathrm{~h}$ and $8 \mathrm{~h}$ the food vacuoles of parasites incubated with Z-Phe-Arg- $\mathrm{CH}_{2} \mathrm{~F}$ were abnormally dark-staining due to a block in globin hydrolysis (see Fig. 3). After $24 \mathrm{~h}$, control parasites developed to multinucleated schizonts, but parasites incubated with Z-Phe-Arg- $\mathrm{CH}_{2} \mathrm{~F}$ had not developed beyond the abnormal trophozoite forms seen earlier.

caused by Z-Phe-Arg- $\mathrm{CH}_{2} \mathrm{~F}$ was mediated by the inhibition of TCP.

$\mathrm{Z}-\mathrm{Phe}-\mathrm{Arg}-\mathrm{CH}_{2} \mathrm{~F}$ was nontoxic to cultured mammalian cells. Many of the fluoromethyl ketones studied, including ZPhe-Arg- $\mathrm{CH}_{2} \mathrm{~F}$, are effective inhibitors of cathepsin $\mathrm{L}$ and other host lysosomal cysteine proteinases (20). It might therefore be assumed that such compounds would be toxic to host cells and not appropriate as chemotherapeutic agents. However, other inhibitors of lysosomal cysteine proteinases, including the peptide leupeptin, are nontoxic to mammalian cells and experimental animals at micromolar concentrations (23). In order to assess the toxicity of Z-Phe-Arg- $\mathrm{CH}_{2} \mathrm{~F}$, we incubated the inhibitor with four different human cell lines-human foreskin fibroblasts, MRC-5 (human fetal lung), Int 407 (human embryonic intestine), and Flow 2000 (human fetal lung)

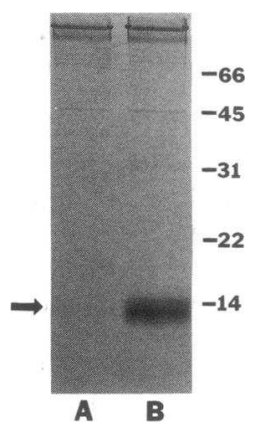

Figure 3. Z-Phe-Arg- $\mathrm{CH}_{2} \mathrm{~F}$ caused the accumulation of undegraded globin. Synchronized ring-stage parasites were cultured $(A)$ without and $(B)$ with $100 \mathrm{nM}$ Z-Phe-Arg- $\mathrm{CH}_{2} \mathrm{~F}$. After $24 \mathrm{~h}$ of culture, when the parasites were at the trophozoite stage, erythrocyte membranes were lysed with $0.1 \%$ saponin, the parasites were washed three times with PBS, and parasite proteins were solubilized in SDS sample buffer and separated by SDS-PAGE (15\% polyacrylamide gel) under reducing conditions. The gel was then stained with Coomassie Blue. The positions of molecular weight standards (in thousands) are labeled. The arrow shows the position of undegraded globin monomers (the protein migrated identically to human hemoglobin under reducing conditions) that were seen only in parasites that were incubated with Z-Phe-Arg- $\mathrm{CH}_{2} \mathrm{~F}$. -for $4 \mathrm{~d}$ and assessed toxicity daily by cell counts, the microscopic appearance of the cells, staining with trypan blue, which stains only nonviable cells, and 3-(4,5-dimethylthiazol-2-yl)2,5-diphenyl tetrazolium bromide reduction, which produces a detectable product in viable cells (17). At concentrations of Z-Phe-Arg- $\mathrm{CH}_{2} \mathrm{~F}$ up to $100 \mu \mathrm{M}$, no appreciable toxicity was noted in any cell line.

\section{Discussion}

We previously hypothesized that TCP is required for the degradation of host erythrocyte hemoglobin by $P$. falciparum trophozoites (7). In order to test this hypothesis we evaluated the effects of a panel of fluoromethyl ketone peptide proteinase inhibitors on TCP and on cultured parasites. Though the effectiveness of the peptides varied over a wide range of concentrations, the concentration at which each peptide inhibited hemoglobin degradation and parasite multiplication correlated with the concentration at which the peptide inhibited the activity of isolated TCP. In each case, the inhibition of biological pro-

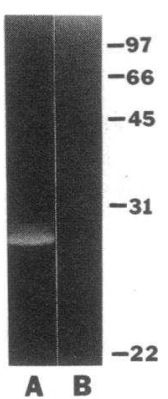

Figure 4. Inhibition of TCP by Z-Phe-Arg- $\mathrm{CH}_{2} \mathrm{~F}$. Gelatin substrate SDS-PAGE (12.5\% polyacrylamide gel) of soluble trophozoite proteins was performed. In control trophozoite extract (lane $A$ ) a clear band at $\mathrm{Mr} 28,000$ represented TCP. For lane $B$, Z-Phe-Arg$\mathrm{CH}_{2} \mathrm{~F}(100 \mathrm{nM})$ was incubated with trophozoite extract ( $1 \mathrm{~h}$ on ice) before the addition of electrophoresis sample buffer and was also added to the buffer $(0.1$ $\mathrm{M}$ sodium acetate, $\mathrm{pH} 6.0,10 \mathrm{mM}$ dithiothreitol) in which the gel lane incubated (overnight at $37^{\circ}$ ) before it was stained with Coomassie Blue. No evidence of proteinase activity was seen in this lane. 
cesses in intact parasites required about two orders of magnitude greater concentrations of the peptides than the inhibition of isolated TCP activity. The fact that increased concentrations of peptides were required to demonstrate biological effects can most likely be explained by limitations in the transport of the inhibitors across erythrocyte and parasite membranes to the malarial food vacuole. Since the inhibition of TCP correlated with a block in hemoglobin degradation and parasite multiplication, our results support the hypothesis that TCP is required for hemoglobin degradation and normal parasite development.

$P$. falciparum trophozoites transport erythrocyte cytoplasm to a central food vacuole where erythrocyte cytoplasmic contents, which consist primarily of hemoglobin, are degraded (5). The peptide fluoromethyl ketone inhibitors induced a characteristic morphological abnormality in the food vacuole. After incubation with the appropriate concentration of peptide, food vacuoles were abnormally large and dark staining. It appeared that erythrocyte cytoplasm was transported normally to the food vacuole, but that the degradation of cytoplasmic components was blocked. To determine whether the peptides induced a specific block in globin hydrolysis, we examined the proteins of Z-Phe-Arg- $\mathrm{CH}_{2} \mathrm{~F}$-treated parasites using SDS-PAGE. After treatment with Z-Phe-Arg- $\mathrm{CH}_{2} \mathrm{~F}$, and the development of the characteristic food vacuole abnormality, parasites contained large quantities of globin monomers. Thus, the development of the food vacuole morphological abnormality upon treatment with Z-Phe-Arg- $\mathrm{CH}_{2} \mathrm{~F}$ appeared to result from a specific block in globin hydrolysis.

We showed that $\mathrm{Z}$-Phe-Arg- $\mathrm{CH}_{2} \mathrm{~F}$ was a very potent inhibitor of TCP using both a fluorescent assay and gelatin substrat PAGE. Since TCP was the only cysteine proteinase identified in trophozoite extracts $(7,8)$ and since it was fully inhibited by the specific peptide inhibitor Z-Phe-Arg- $\mathrm{CH}_{2} \mathrm{~F}$, we propose that the biological effects of $\mathrm{Z}$-Phe-Arg- $\mathrm{CH}_{2} \mathrm{~F}$ were due specifically to the inhibition of TCP. Since the inhibition of parasite development and multiplication induced by Z-Phe-Arg- $\mathrm{CH}_{2} \mathrm{~F}$ correlated with the inhibition of hemoglobin degradation, our data support the hypothesis that TCP is an essential trophozoite hemoglobinase.

As TCP appears to be a necessary trophozoite hemoglobinase, and as hemoglobin degradation is a process unique to intraerythrocytic malaria parasites, TCP is a promising target for antimalarial chemotherapy. Z-Phe-Arg- $\mathrm{CH}_{2} \mathrm{~F}$, the most potent TCP inhibitor we studied, acted rapidly and irreversibly, and had identical effects on four different strains of $P$. falciparum that varied in geographic origins and chloroquine sensitivity. Z-Phe-Arg- $\mathrm{CH}_{2} \mathrm{~F}$ was effective at nanomolar concentrations that were approximately equal to effective concentrations of the antimalarial quinine in similar assays of cultured parasites (24). The effective concentrations of Z-Phe-Arg- $\mathrm{CH}_{2} \mathrm{~F}$ were far below those that were nontoxic to four human cell lines. It is not known why Z-Phe-Arg- $\mathrm{CH}_{2} \mathrm{~F}$ and other potent inhibitors of host cysteine proteinases such as leupeptin (23) are nontoxic to mammalian cells. In studies of intact organisms, another of the fluoromethyl ketones studied, Z-Phe-Ala- $\mathrm{CH}_{2} \mathrm{~F}$, was relatively nontoxic to mice, with an $\mathrm{LD}_{50}(360 \mathrm{mg} / \mathrm{kg})$ roughly $500 \times$ the oral dose necessary to inhibit cathepsin $B$ activity and block the development of experimental arthritis in rats $(25$, 26). The lack of toxicity of Z-Phe-Arg- $\mathrm{CH}_{2} \mathrm{~F}$ and Z-Phe-Ala$\mathrm{CH}_{2} \mathrm{~F}$ might be due to inefficient transport of the compounds into mammalian cells. Parasite-infected erythrocytes (and subsequently malarial food vacuoles) may attain significantly higher levels of the fluoromethyl ketones than most host cells due to the increased permeability of erythrocytes induced by infection with malaria parasites (27). Alternatively, the inhibitors may reach inhibitory levels in mammalian cells (as was the case with Z-Phe-Ala- $\mathrm{CH}_{2} \mathrm{~F}$ in an experimental arthritis model in rats [26]), but these cells may be able to tolerate the inhibition of cysteine proteinases, perhaps due to the presence of numerous other intracellular proteolytic systems, including other classes of lysosomal proteinases (28).

In summary, our results support the hypothesis that TCP is required by $P$. falciparum trophozoites for the degradation of host hemoglobin. The results further suggest that TCP is a suitable target for antimalarial chemotherapy, as malaria parasites appear to be much more susceptible than host cells to the inhibition of cathepsin L-like enzymes. Z-Phe-Arg- $\mathrm{CH}_{2} \mathrm{~F}$, the most potent inhibitor of TCP that we identified, effectively blocked parasite development at concentrations far below those shown to be nontoxic to mammalian cells. Thus, Z-Phe-Arg- $\mathrm{CH}_{2} \mathrm{~F}$ and other peptide and nonpeptide inhibitors of TCP appear to be worthy of further testing as a potential antimalarial drug.

\section{Acknowledgments}

We thank Garson Lee for his expert technical assistance and Drs. Joel Ernst, James Leech, James McKerrow, and Richard Nelson for their advice during the course of these studies and their critical reviews of the manuscript.

This work was supported by grants from the National Institutes of Health (AI-00870), the UNDP/World Bank/WHO Special Programme for Research and Training in Tropical Diseases (TDR 890499), and the Academic Senate of the University of California, San Francisco.

\section{References}

1. Wyler, D. J. 1983. Malaria-resurgence, resistance, and research. $N$. Engl. J. Med. 308:875-878, 934-940.

2. Walsh, J. A. 1989. Disease problems in the Third World. Ann. N.Y. Acad. Sci. 569:1-16.

3. Bruce-Chwatt, L. J. 1986. Chemotherapy of Malaria. World Health Organization, Geneva.

4. Moran, J. S., and K. W. Bernard. 1989. The spread of chloroquine-resistant malaria in Africa. JAMA (J. Am. Med. Assoc.) 262:245-248.

5. Sherman, I. W. 1979. Biochemistry of Plasmodium (malarial parasites). Microbiol. Rev. 43:453-495.

6. Krogstad, D. J., and P. H. Schlesinger. 1987. Acid-vesicle function, intracellular pathogens, and the action of chloroquine against Plasmodium falciparum. N. Engl. J. Med. 317:542-549.

7. Rosenthal, P. J., J. H. McKerrow, M. Aikawa, H. Nagasawa, and J. H. Leech. 1988. A malarial cysteine proteinase is necessary for hemoglobin degradation by Plasmodium falciparum. J. Clin. Invest. 82:1560-1566.

8. Rosenthal, P. J., K. Kim, J. H. McKerrow, and J. H. Leech. 1987. Identification of three stage-specific proteinases of Plasmodium falciparum. J. Exp. Med. 166:816-821.

9. Rosenthal, P. J., J. H. McKerrow, D. Rasnick, and J. H. Leech. 1989. Plasmodium falciparum: inhibitors of lysosomal cysteine proteinases inhibit a trophozoite proteinase and block parasite development. Mol. Biochem. Parasitol. 35:177-184.

10. Ondetti, M. A., B. Rubin, and D. W. Cushman. 1977. Design of specific inhibitors of angiotensin-converting enzyme: new class of orally active antihypertensive agents. Science (Wash. DC). 196:441-444.

11. Kostis, J. B., J. J. Raia, E. A. DeFelice, J. A. Barone, and R. G. Deeter. 1987. Comparative clinical pharmacology of ACE inhibitors. In Angiotensin Converting Enzyme Inhibitors. J. B. Kostis and E. A. DeFelice, editors. Alan R. Liss, Inc., New York. 19-54.

12. Meek, T. D., D. M. Lambert, G. B. Dreyer, T. J. Carr, T. A. Tomaszek, M. L. Moore, J. E. Strickler, C. Debouck, L. J. Hyland, T. J. Matthews, et al. 1990. Inhibition of HIV-1 protease in infected T-lymphocytes by synthetic peptide analogues. Nature (Lond.). 343:90-92.

13. McQuade, T. J., A. G. Tomasselli, L. Liu, V. Karacostas, B. Moss, T. K. Sawyer, R. L. Heinrikson, and W. G. Tarpley. 1990. A synthetic HIV-1 protease 
inhibitor with antiviral activity arrests HIV-like particle maturation. Science (Wash. DC). 247:454-456.

14. Roberts, N. A., J. A. Martin, D. Kinchington, A. V., Broadhurst, J. C. Craig, I. B. Duncan, S. A. Galpin, B. K. Handa, J. Kay, A. Krohn, et al. 1990 Rational design of peptide-based HIV proteinase inhibitors. Science (Wash. DC) 248:358-361.

15. Salvesen, G., and H. Nagase. 1989. Inhibition of proteolytic enzymes. In Proteolytic Enzymes. R. J. Beynon and J. S. Bond, editors. IRL Press, Oxford. 83-104.

16. Barrett, A. J., and H. Kirschke. 1981. Cathepsin B, cathepsin H, and cathepsin L. Methods Enzymol. 80:535-561.

17. Denizot, F., and R. Lang. 1986. Rapid colorimetric assay for cell growth and survival. J. Immunol. Methods. 89:271-277.

18. Rasnick, D. 1985. Synthesis of peptide fluoromethyl ketones and the inhibition of human cathepsin B. Anal. Biochem. 149:461-465.

19. Rauber, P., H. Angliker, B. Walker, and E. Shaw. 1986. The synthesis of peptidylfluoromethanes and their properties as inhibitors of serine proteinases and cysteine proteinases. Biochem. J. 239:633-640.

20. Angliker, H., P. Wikstrom, P. Rauber, S. Stone, and E. Shaw. 1988 Synthesis and properties of peptidyl derivatives of arginylfluoromethanes. Biochem. J. 256:481-486.

21. Rich, D. H. 1986. Inhibitors of cysteine proteinases. In Proteinase Inhibi- tors. A. J. Barrett and G. Salvesen, editors. Elsevier Science Publishers, Amsterdam.

22. Rockett, K. A., J. H. L. Playfair, F. Ashall, G. A. T. Targett, H. Angliker, and E. Shaw. 1990. Inhibition of intraerythrocytic development of Plasmodium falciparum by proteinase inhibitors. FEBS (Fed. Eur. Biochem. Soc.) Lett. 259:257-259.

23. Seglen, P. O. 1983. Inhibitors of lysosomal function. Methods Enzymol. 96:737-764.

24. Geary, T. G., and J. B. Jensen. 1983. Lack of cross-resistance to 4-aminoquinolines in chloroquine-resistant Plasmodium falciparum in vitro. J. Parasitol. 69:97-105.

25. Smith, R. E., D. Rasnick, C. O. Burdick, K. Cho, J. C. Rose, and A. Vahratian. 1988. Visualization of time-dependent inactivation of human tumor cathepsin B isozymes by a peptidyl fluoromethyl ketone using a fluorescent print technique. Anticancer Res. 8:525-530.

26. van Noorden, C. J. F., R. E. Smith, and D. Rasnick. 1988. Cysteine proteinase activity in arthritic rat knee joints and the effects of a selective systemic inhibitor, Z-Phe-AlaCH ${ }_{2}$ F. J. Rheumatol. 15:1525-1534.

27. Cabantchik, Z. I. 1989. Altered membrane transport of malaria-infected erythrocytes: a possible pharmacologic target. Blood. 74:1464-1471.

28. Bond, J. S., and P. E. Butler. 1987. Intracellular proteases. Annu. Rev. Biochem. 56:333-364. 